\title{
Application of the Theory of Brainstorming in Visual Teaching of Music
}

\author{
https://doi.org/10.3991/ijet.v16i24.27837 \\ Nan Lin $\left.{ }^{(}\right)$, Jiannan Li \\ Cangzhou Normal University, Cangzhou, China \\ czsyross@caztc.edu.cn
}

\begin{abstract}
Visual teaching is a teaching method or teaching tool that presents a clearer and more intuitive image of music works to students. Drawing on the theory of brainstorming, this paper explores the application of brainstorming, a brain stimulation method, in visual teaching of music. The main results are as follows: visual music teaching mainly improves music skills, cultivates music aesthetics, and enhances communicative competence. Once introduced to music class, the creative thinking method of brainstorming enables the teacher to train the divergent and creative thinking of students. During music teaching, brainstorming stimulates the learning interest, boosts the learning confidence, and cultivates the independent thinking of students. The research findings lay a theoretical basis for music course reform.
\end{abstract}

Keywords - visual teaching, teaching tool, theory of brainstorming, music skills, music aesthetics

\section{Introduction}

Music class is a good way to cultivate students' aesthetic taste and cultural qualities [1]. In music teaching, educators should enrich and rationalize the teaching methods and tools, pay attention to students' overall feeling of the music class and music teaching, and enable them to fully experience the charm of music as an art form $[2,3]$ visualization of music teaching is a psychological phenomenon of music produced based on synesthesia, and it contains a variety of music teaching methods [4]. In actual teaching process, music teachers actively attempt to give back the class to students, and apply more interesting music teaching methods to the students $[5,6]$.

The visual teaching of music class can stimulate students' interest in music and help them better understand and enjoy the music works, especially for students in lower grades [7]. After listening to music, some students can dance to the rhythm, and get a complete musical experience [8]. With the advancement and application of information technology, the visualization of music teaching has undergone big changes, visual expression tools are used more often to form concept maps, mind maps and other visual methods to help students understand music better [9]. Many factors can affect the visual teaching of music, such as the teacher's information technology skills and the visual teaching platforms and tools, etc. [10]. To carry out visual teaching in music class, it's 
necessary to ensure that students can participate in the whole process autonomously, this is very helpful for learners to have a cognition of the learning content, thereby obtaining a better sense of self-efficacy $[11,12]$. The visual teaching of music class also needs to take into account the interactivity of visual teaching, so that the teacher could communicate with students closer and make the music teaching activities more vivid and attractive [13].

The theory of brainstorming is called by many names such as the brain stimulation method, the multiple thinking method, and the free association method [14]. Brainstorming is not just a teaching method, but also a way of learning and sharing with unique value $[15,16]$. Music teaching is a form of artistic activity of human, combining the characteristics of brainstorming with language teaching is a re-creation of human thinking and expression methods [17]. Music teaching is also a process containing teaching environment, teaching content, teaching methods, teaching activities and teacher-student interaction, and the application of brainstorming can effectively connect all teaching activities in this process [18]. Applying brainstorming to music teaching is an embodiment of music teaching methods and theories [19, 20]. Some researchers compared brainstorming with other teaching methods, and found that the traditional teaching methods generally lack interaction in the classroom, the teaching effect is not good, and it's difficult to mobilize students' learning initiative [21]. Therefore, this paper attempts to explore the brainstorming theory, apply it to the visual teaching of music class, and offer theoretical evidence to the reform of music course.

\section{The visual teaching of music class}

\subsection{The positive role of visual teaching in music class}

Visual thinking emphasizes on the thinking, sorting, and reorganizing of observed matters, while the audiovisual synesthesia emphasizes the interaction between hearing and vision [22]. In music teaching, there are many visualized expression methods such as mind maps, music scores, and music elements, etc. [23]. The teaching of musical scores and notes guided by the theory of multimedia learning is in line with the melodic feature of the music discipline [24]. In the visual teaching of music class, teachers use multimedia to integrate music, images, videos, and other visual elements, and bring students with an intuitive musical experience from both visual and auditory aspects [25]. The visual teaching of audios and videos is more intuitive than images, audios and videos can replace teacher's language to give students the most vivid visual experience [26].

Figure 1 shows the design process of visual teaching activities. The visual teaching design runs through the entire teaching process. Before visual teaching, teachers need to analyze the specific teaching content comprehensively to clarify the specific teaching forms; after completing the visual teaching works, they also need to evaluate the entire process of visual teaching, find out problems in the visual teaching design, then modify 
the problems and optimize the design. Elements included in the visual teaching activities contain the teaching content, teaching goals, learner analysis, organizational form, support plan, activity rules, and activity evaluation, etc. [27].

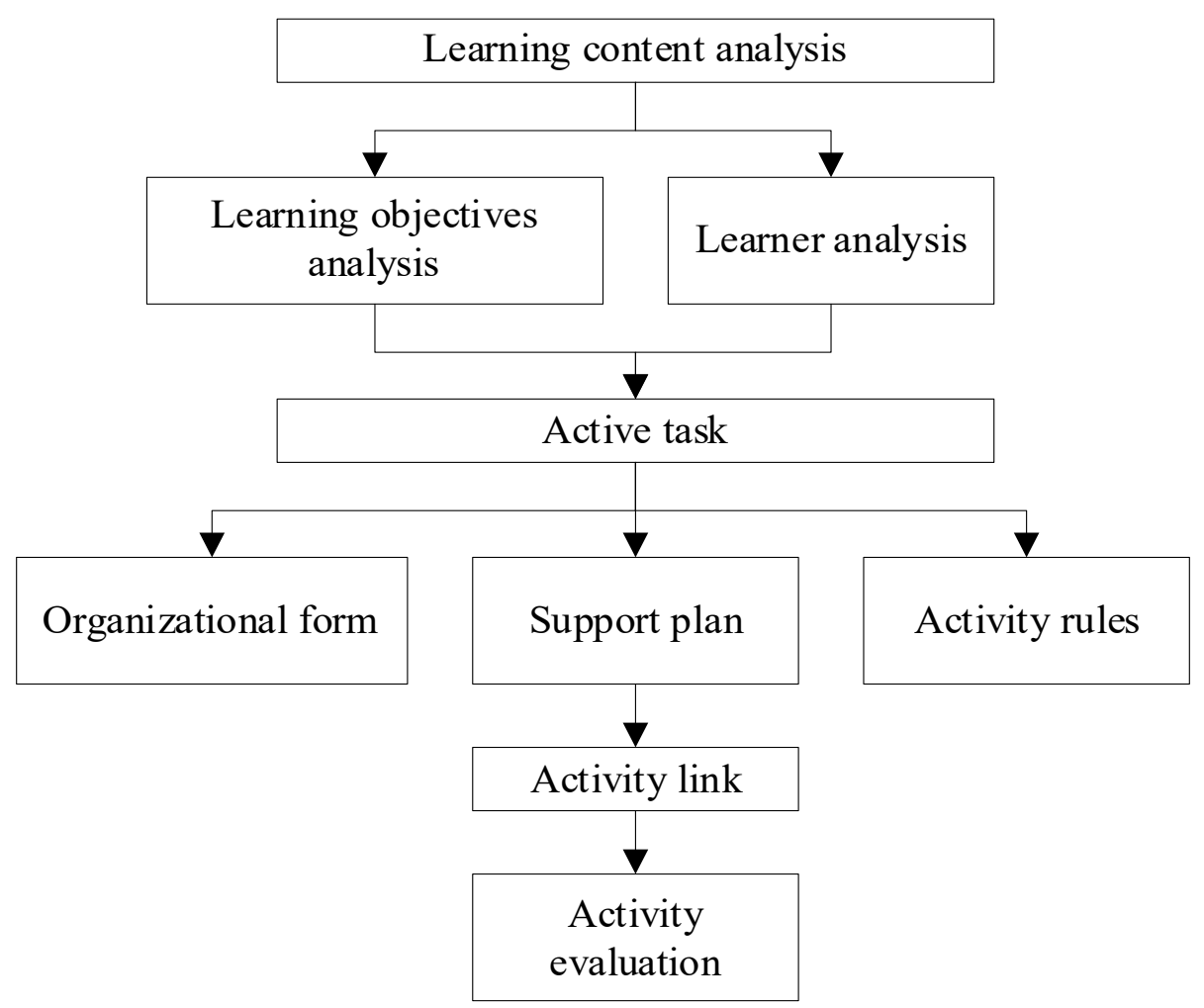

Fig. 1. Design process of visual teaching activities

\subsection{The status quo of visual teaching in music class}

Our research team investigated the state quo of visual teaching in music class, Table 1 gives the survey results, the respondents include students and teachers, all students are form a middle school in Wuhan city, China, and the effective rate of the questionnaires is more than $96 \%$. The survey content includes the students' fondness of music class, their evaluation on music teaching, the teaching content of music class, and their solutions for problems, etc. Figure 2 shows the reasons why students like the music class, $33.33 \%$ of them like it as an expression of themselves, $28.31 \%$ and $23.54 \%$ of them like it because of the attraction and the rhythm of the music, respectively. Figure 3 shows the students' evaluation on the visual teaching of music class, more than $50 \%$ of the students like it or like it very much. Figure 4 shows the teaching content of music class of each grade. The most popular teaching content is music singing, followed by 
music appreciation and basic music knowledge, and students do not like music performance or music creation very much. Figure 5 shows the solutions of students when they encounter questions in music teaching. $53.76 \%$ of them will seek guidance from teachers, $33.8 \%$ of them determine to solve the problems by themselves, and other students choose to ignore the problems or leave them unsolved. Figure 6 shows the functions of visual teaching in music class, the primary functions are to improve music skills, cultivate music aesthetics, and enhance communicative competence.

Table 1. Basic information of the questionnaire survey

\begin{tabular}{|l|c|c|c|c|}
\hline Respondents & Distributed questionnaire & Returned questionnaire & Recovery rate & Effective rate \\
\hline Student & 571 & 569 & $99.65 \%$ & $96.15 \%$ \\
\hline Teacher & 42 & 42 & $100 \%$ & $97.62 \%$ \\
\hline
\end{tabular}

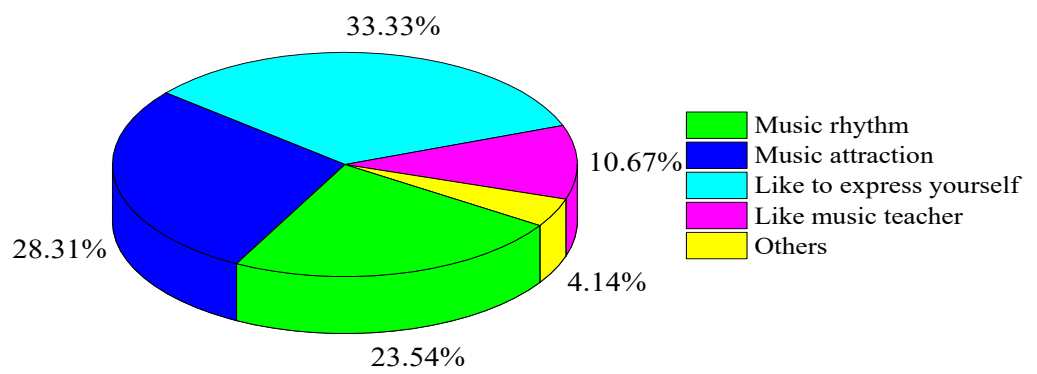

Fig. 2. Reasons why students like the music class

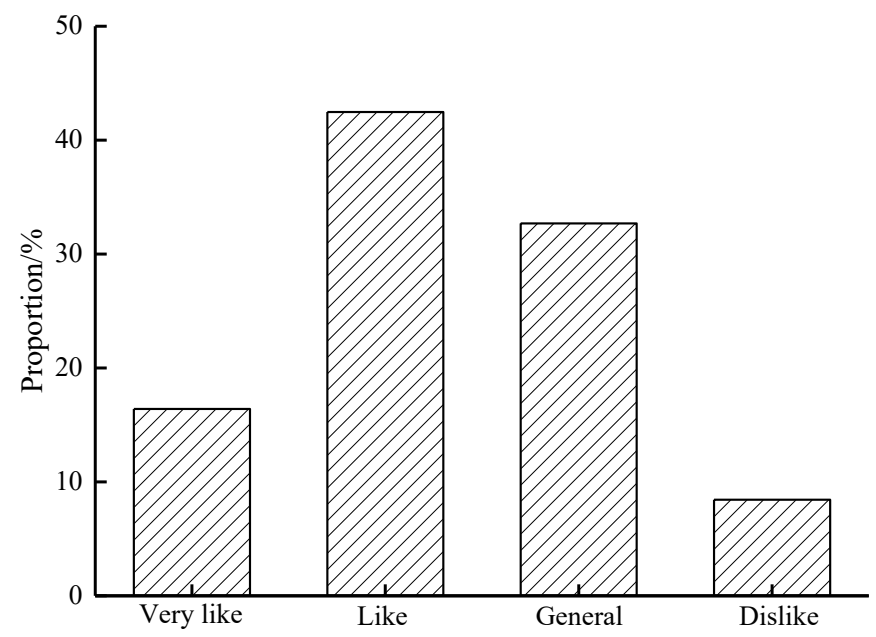

Fig. 3. Students' evaluation on the visual teaching of music class 


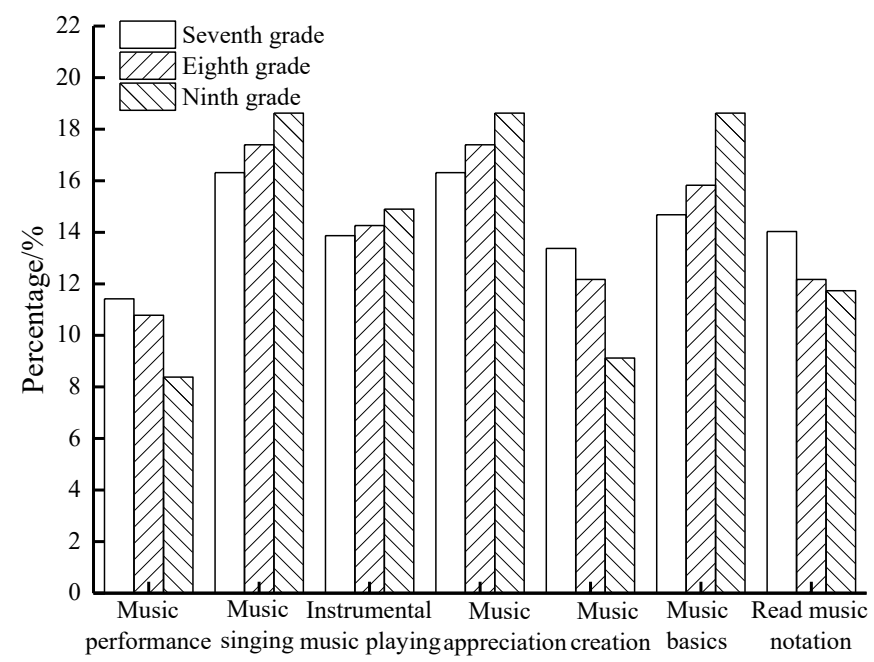

Fig. 4. Teaching content of music class of each grade

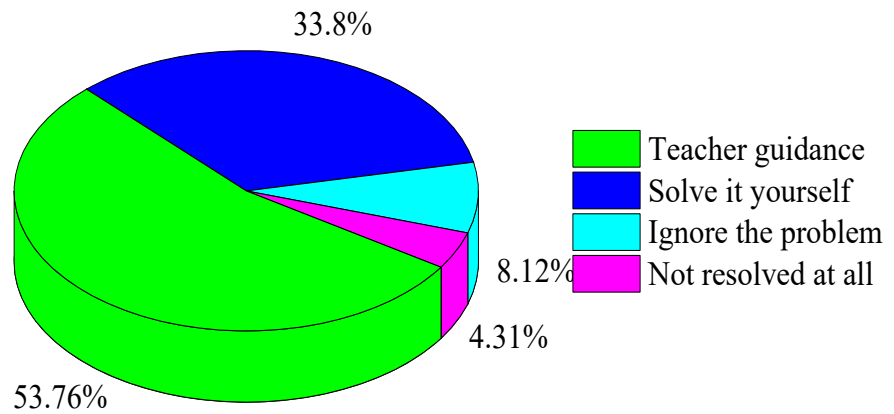

Fig. 5. Solutions of students when they encounter questions in music teaching

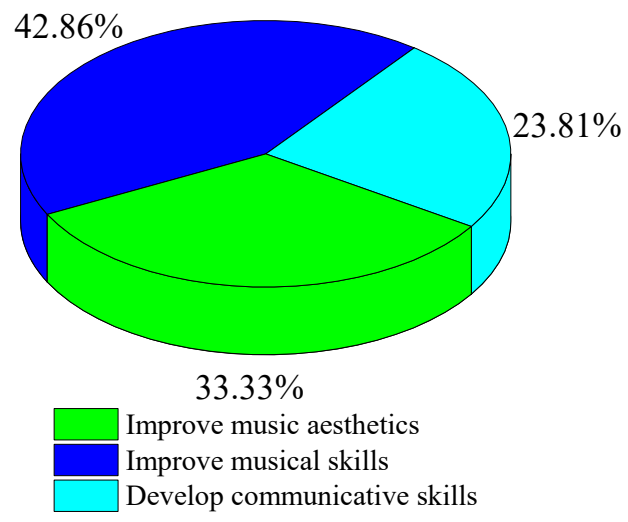

Fig. 6. Functions of visual teaching in music class 


\section{The application of brainstorming theory in music teaching}

\subsection{Necessity}

At present, the teaching form of music class in middle schools and elementary schools is fixed [28, 29]. However, as students can get more information in these days, the stereotyped teaching form not only affects teachers' enthusiasm for teaching, but also kills students' enthusiasm for music learning [30, 31]. In music teaching, it's not that each teaching module exists separately, the design of each visual module emphasizes independent learning and cooperative learning. To improve the teaching efficiency of music class and avoid single, solidified, and uncreative teaching methods, the visual teaching should be introduced into the teaching of music class. Brainstorming is a creative thinking method, introducing it into music class can help teachers train the divergent thinking and creative thinking of students.

Figure 7 shows the principles of the brainstorming theory, first, it encourages "free imagination", applying brainstorming in music class enables students to think freely, use their imagination to the greatest extent, and overcome inertial thinking and laziness. The second principle is the principle of deferred judgment, which means to trigger students' thinking of any idea through rich associations and connections. The third is the quantity and quality principle, no thinking or idea is immutable, people should learn to break through traditions and limitations, and highlight more creative and valuable ideas. The fourth principle is to explore research combinations and improve concepts, meaning to inspire students to consider other ideas other than their original thoughts by themselves.

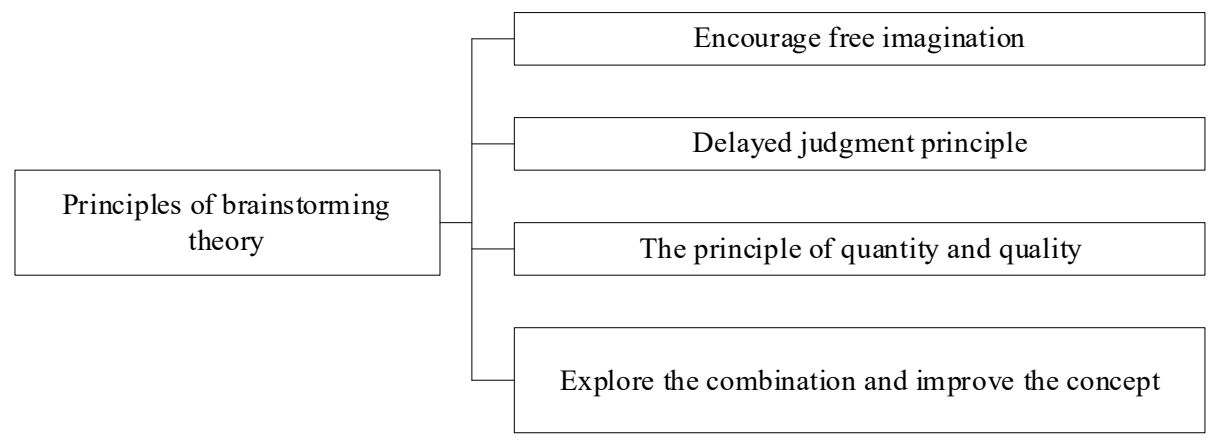

Fig. 7. Principles of the brainstorming theory

\subsection{Feasibility}

Figure 8 shows the relationship between the visualization of music education and relevant disciplines. As can be seen from the figure, the visualization of music education is related to many disciplines, with music acoustics as the scientific basis, humancomputer interaction, sensing and control technique, and computer and information 
technology as supports, it is closely related to music images and graphics. The application forms of visualization in music field include music creation, music performance, music research, and music education. Before introducing brainstorming into music teaching, it's necessary to clarify the problems need to be solved and the requirements of music teaching first. Students' music attainment is inseparable from the formation of their cognition structure of art. Music class is different from other majors and their main courses, music class is fun, by creating certain environment, the classroom atmosphere could be activated. For art such as music, creativity is the art of teaching. By introducing brainstorming into music teaching, we can trigger students' interest in music learning, give them more initiative, and let them be the real master of the music stage. Brainstorming can effectively provide help for the interaction in the classroom, allowing students to better participate in the class, triggering their learning interest, increasing their learning information, and cultivating their habit of independent thinking.

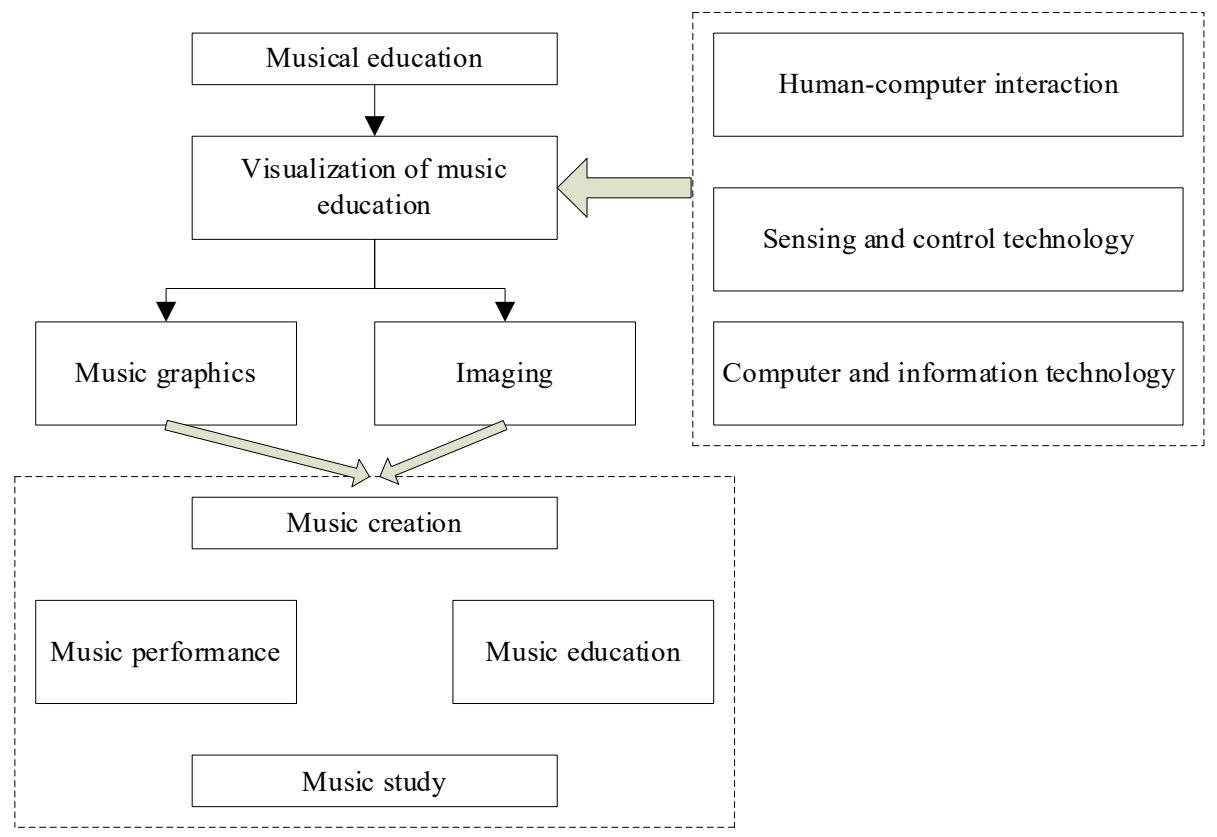

Fig. 8. Relationship between the visualization of music education and relevant disciplines

\section{The effect of brainstorming in the visual teaching of music class}

The visualization of music education includes many music teaching methods. Any method that can convert music art into a visible thing and convey similar feelings to people can be called a visual teaching method of music. During the survey, we discovered a situation that many teachers are unwilling to take the music appreciation course and the music creation course because they don't know how to instruct children to listen 
and analyze. Figure 9 gives two examples of the visual expression of music, which can show the rhythm of music through visual effect to achieve the purpose of music appreciation. Brainstorming surpasses the traditional classroom teaching method, it guarantees students' dominant position in the class, allows them to experience music more intuitively, excites the rhythm and melody in their own body, and guides them to actively participate in music performance activities.

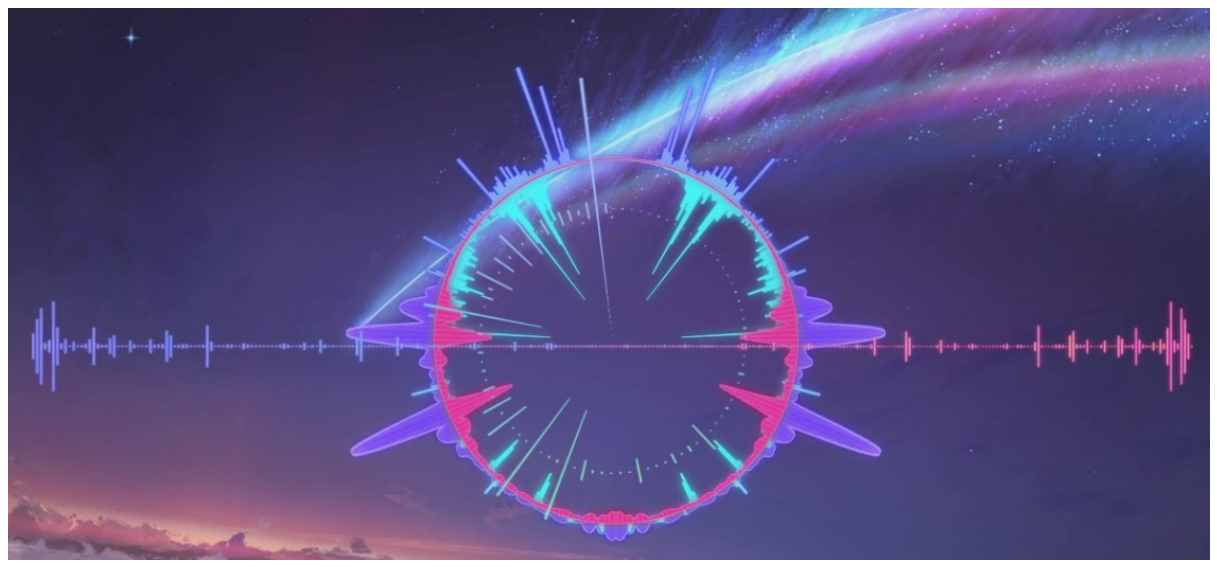

(a)

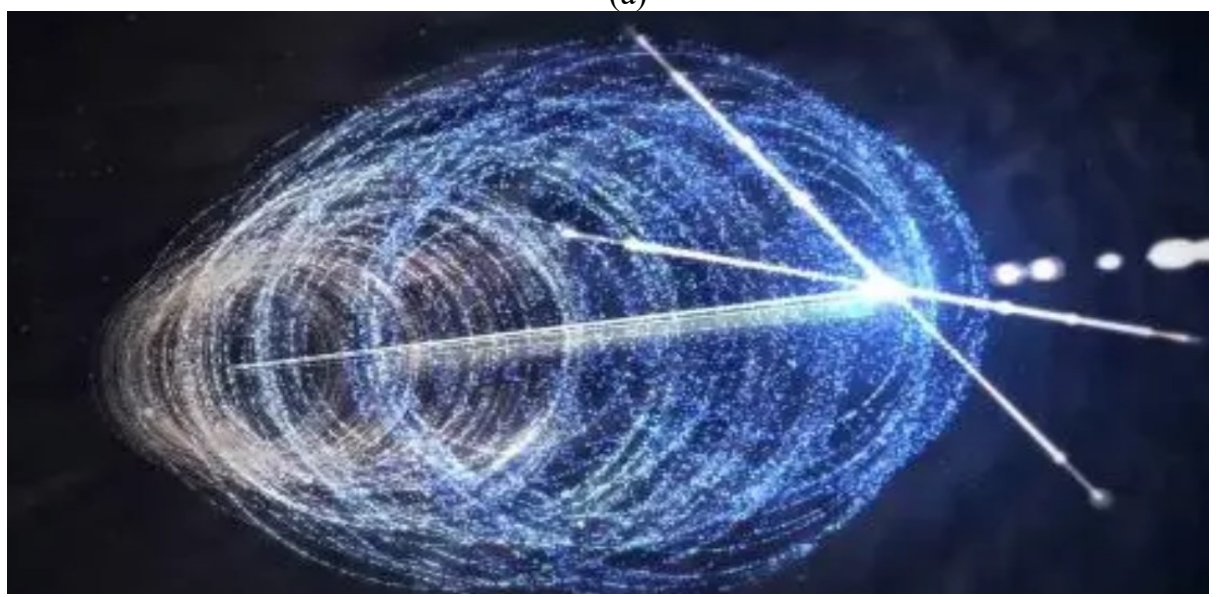

(b)

Fig. 9. Visual expression of music

\section{The role of visual analysis in music teaching}

Figure 10 summarizes the deficiencies in current music teaching. In terms of students, some students do not have a correct learning attitude, some students' basic knowledge is not solid enough, and some students' music quality needs to be improved. The visual analysis in music teaching can cultivate students' music appreciation ability, 
help them accumulate music knowledge, and stimulate their creativity in music learning. In terms of teachers, some teachers' music attainment cannot meet the teaching requirements, teachers haven't received sufficient training for music teaching and research, the work load of music teachers is large, a music teacher often needs to undertake the music course of at least ten classes. In terms of schools, the budge for music teaching is often very limited, usually there's very few venues and instruments for music teaching, and the school leaders generally pay insufficient attention to music teaching.

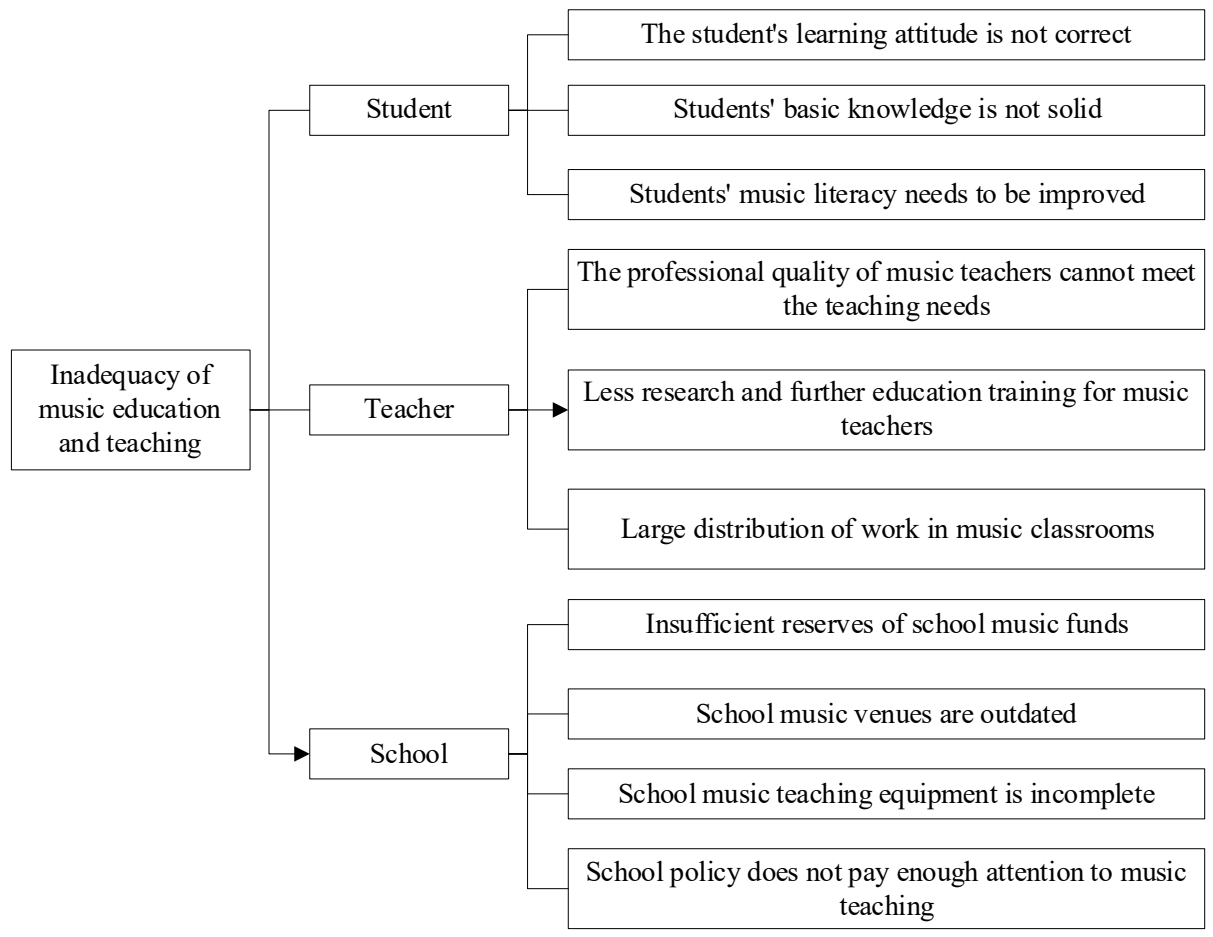

Fig. 10. Deficiencies in current music teaching

Figure 11 is a statistic of the visual teaching tools for music class, including slides, electronic piano, projector, multimedia, and computer, etc. Figure 12 shows the evaluation on the visual analysis of music teaching. $75.34 \%$ of the respondents think that visual analysis is very necessary for music teaching, $17.81 \%$ of them think it's necessary, that is, more than $93 \%$ of the respondents consider visual analysis as a necessity for music teaching. Figure 13 lists a few countermeasures proposed by this paper for enhancing the effect of visual teaching in music class. We should correctly trigger students' interest in music learning, cater to the music taste of students in the new era, build the teaching idea of taking students as the dominant party of education, mobilize students' initiative in music learning, pay attention to music visualization in teaching, 
and make use of the visual teaching tools reasonably; through brainstorming, we can create an active classroom atmosphere and organize students to participate in some extracurricular music activities, thereby expanding their music vision and cultivating them to have a lifelong interest in music. In addition, the music teachers' professionalism and teaching level should be improved; extracurricular music activities could be developed to enrich students' music activities outside the schools, and the interaction between music teachers and students should be increased. Moreover, we should also optimize the music course evaluation system of teachers and students, adhere to the principles of music course evaluation, and diversify the evaluation system of music course.

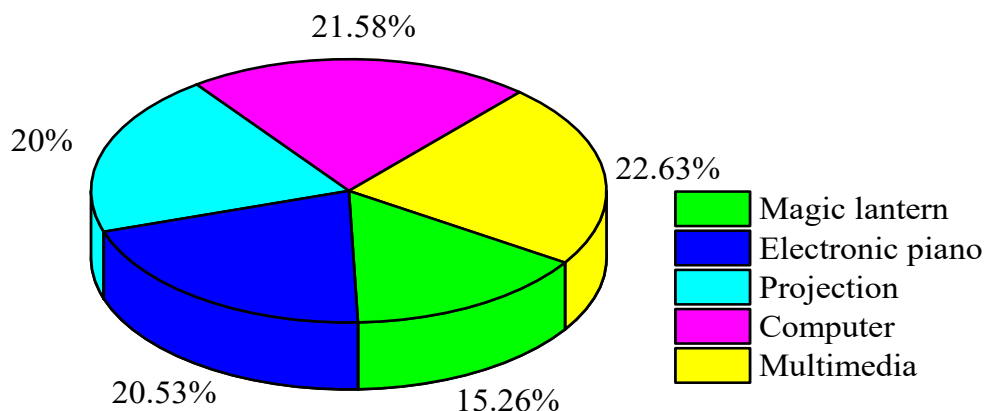

Fig. 11. Visual teaching tools for music class

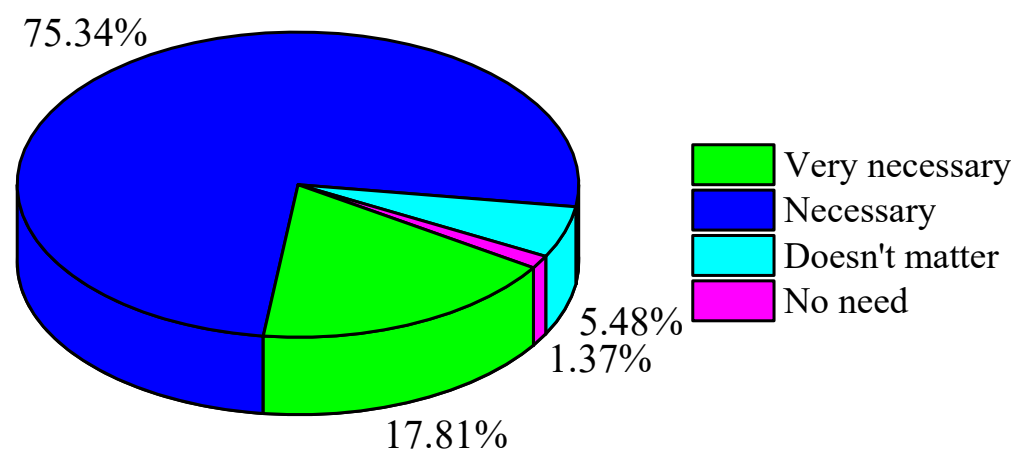

Fig. 12. Evaluation on the visual analysis of music teaching 


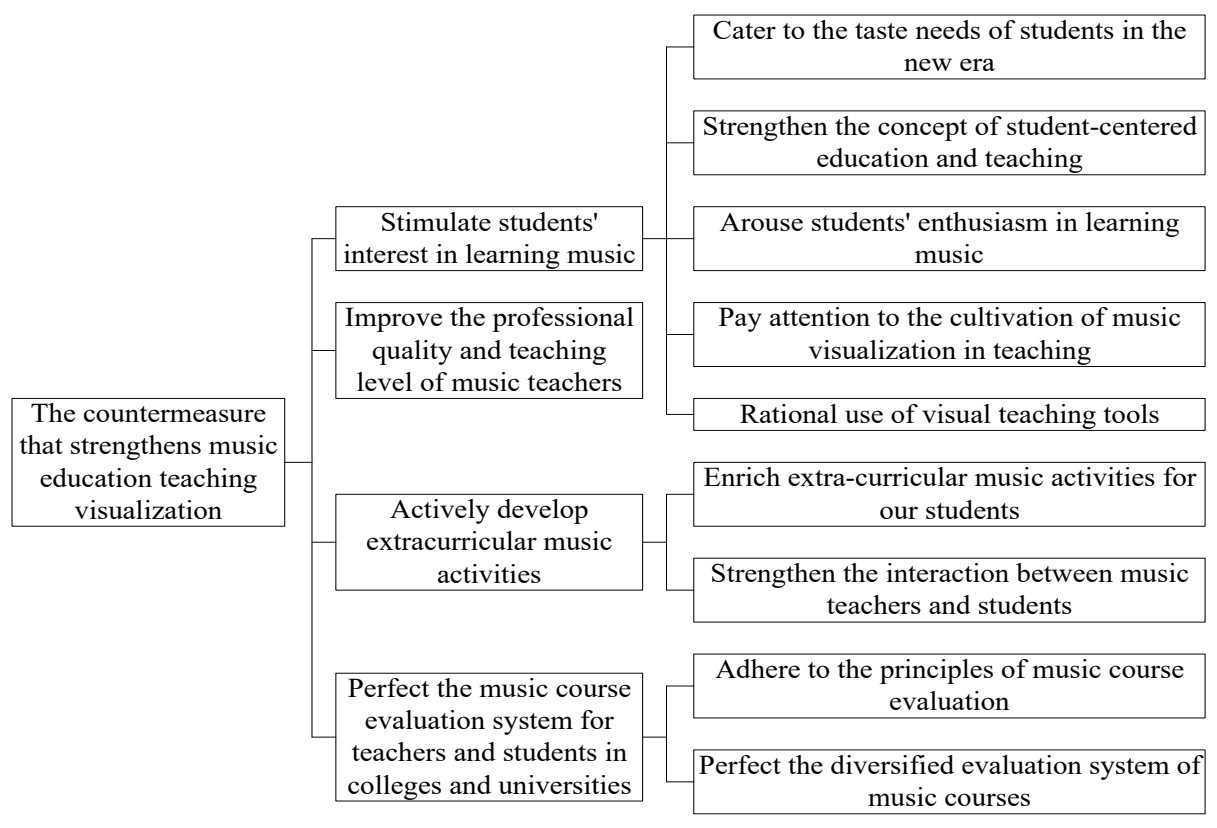

Fig. 13. Countermeasures for enhancing the effect of visual teaching in music class

\section{Conclusions}

Based on the theory of brainstorming, this paper explored the application of brainstorming in the visual teaching of music class, and obtained following conclusions:

1. More than $50 \%$ of the students like visual teaching in music class or like it very much. The most popular music teaching content is music singing, followed by music appreciation and basic music knowledge, however, student do not like music performance or music creation very much.

2. Principles of the brainstorming theory include the principle of encouraging free imagination, the principle of deferred judgment, and the quantity and quality principle. No thinking or idea is immutable, we should learn to break through traditions and limitations, and highlight more creative and valuable ideas.

3. Brainstorming surpasses the traditional classroom teaching method, it guarantees students' dominant position in the class, allows them to experience music more intuitively, excites the rhythm and melody in their own body, and guides them to actively participate in music performance activities. 
Paper-Application of the Theory of Brainstorming in Visual Teaching of Music

\section{$7 \quad$ References}

[1] Taylor, P. G. (2007). Press pause: Critically contextualizing music video in visual culture and art education. Studies in Art Education, 48(3): 230-246. https://doi.org/10.1080/ 00393541.2007 .11650103

[2] Draves, T. (2012). Teaching ambition: A case study of high school music students. Music Education Research, 14(3): 1-18. https://doi.org/10.1080/14613808.2012.685463

[3] Katz-Buonincontro, J. (2015). Decorative integration or relevant learning? A literature review of studio arts-based management education with recommendations for teaching and research. Journal of Management Education, 39(1): 81-115. https://doi.org/10.1177/ 1052562914555192

[4] Lawson-Adams, J., Dickinson, D. K. (2020). Sound stories: using nonverbal sound effects to support English word learning in first-grade music classrooms. Reading Research Quarterly, 55(3): 419-441. https://doi.org/10.1002/rrq.280

[5] L. Y.F. (2020). Visual Education of Music Course for College Students Based on HumanComputer Interaction, International Journal of Emerging Technologies in Learning, 15(2): 175-186. https://doi.org/10.3991/ijet.v15i02.12535

[6] Yang, L.Q. (2020). Comprehensive Evaluation of Music Course Teaching Level Based on Improved Multi-attribute Fuzzy Evaluation Model, International Journal of Emerging Technologies in Learning, 15(9): 107-121. https://doi.org/10.3991/ijet.v15i19.17411

[7] Louth. (2020). Emphasis and suggestion versus musical taxidermy: neoliberal contradictions, music education, and the knowledge economy. Philosophy of Music Education Review, 28(1): 88-107. https://doi.org/10.2979/philmusieducrevi.28.1.06

[8] Sepp, A., Ruokonen, I., Ruismäki, H. (2015). Musical practices and methods in music lessons: a comparative study of Estonian and Finnish general music education. Music Education Research, 17(3): 340-358. https://doi.org/10.1080/14613808.2014.902433

[9] Paney, A. S., Buonviri, N. O. (2014). Teaching melodic dictation in advanced placement music theory. Journal of Research in Music Education, 61(4): 396-414. https://doi.org/ $\underline{10.1177 / 0022429413508411}$

[10] Karlsen, S., Westerlund, H. (2010). Immigrant students' development of musical agency exploring democracy in music education. British Journal of Music Education, 27(3): 225239. https://doi.org/10.1017/S0265051710000203

[11] Grace, W., Apthorpe, H. C., Kate, R., Shanika, N. (2018). An innovative educational approach in using instructional videos to teach dental local Anaesthetic skills. European Journal of Dental Education, 23(1): 28-34. https://doi.org/10.1111/eje.12382

[12] Moruzzi, C. (2018). Every performance is a stage: musical stage theory as a novel account for the ontology of musical works. The Journal of Aesthetics and Art Criticism, 76(3): 341 351. https://doi.org/10.1111/jaac.12579

[13] Juntunen, M. L. (2014). Teacher educators' visions of pedagogical training within instrumental higher music education. A case in Finland. British Journal of Music Education, 31(2): 157-177. https://doi.org/10.1017/s0265051714000102

[14] Barroso, C., Ganley, C. M., Hart, S. A., Rogers, N., Clendinning, J. P. (2019). The relative importance of mathand music ln elated cognitive and affective factors in predicting undergraduate music theory achievement. Applied Cognitive Psychology, 33(5): 771-783. https://doi.org/10.1002/acp.3518

[15] Amalia, C. M., Ignacio, P. J., Ignacio, M. (2014). The influence of music learning cultures on the construction of teaching-learning conceptions. British Journal of Music Education, 31(3): 319-342. https://doi.org/10.1017/s0265051714000096 
Paper-Application of the Theory of Brainstorming in Visual Teaching of Music

[16] Bowman, W. (2010). Music education in nihilistic times. Educational Philosophy and Theory, 37(1): 29-46. https://doi.org/10.1111/j.1469-5812.2005.00096.x

[17] Hall, J. L. (2010). Teaching with music: an alternative pedagogy for leadership educators. Journal of Leadership Studies, 3(4): 108-110. https://doi.org/10.1002/jls.20147

[18] Lines, D. (2005). 'working with' music: a heideggerian perspective of music education. Educational Philosophy and Theory, 37(1): 65-75. https://doi.org/10.1111/j.14695812.2005.00098.x

[19] Holly, O., Christopher D., Michelle, S. (2010). Authentic arts-based learning in teacher education: a musical theatre experience. Teaching Education, 21(4): 367-383. https:// doi.org/10.1080/10476210.2010.495770

[20] Draves, T. J. (2018). Molly and Rachel become band teachers: teacher identity construction during music student teaching. Contributions to Music Education, 43: 95-116.

[21] Deborah, B. (2012). Avoiding the "p" word: political contexts and multicultural music education. Theory Into Practice, 51(3): 188-195. https://doi.org/10.1080/00405841. $\underline{2012.690296}$

[22] Johansson, K. (2012). Experts, entrepreneurs and competence nomads: the skills paradox in higher music education. Music Education Research, 14(1): 45-62. https://doi.org/10.1080/ $\underline{14613808.2012 .657167}$

[23] Mateos-Moreno, D., Alcaraz-lborra, M. (2013). Grounded theory as a methodology to design teaching strategies for historically informed musical performance. Music Education Research, 15(2): 231-248. https://doi.org/10.1080/14613808.2013.788139

[24] Booth, E. (2009). The music teaching artist's bible: becoming a virtuoso educator. Oxford University Press. https://doi.org/10.5406/jaesteduc.45.3.0118

[25] Elliott, D. J. (2005). Musical understanding, musical works, and emotional expression: implications for education. Educational Philosophy \& Theory, 37(1): 93-103. https://doi.org/10.1111/j.1469-5812.2005.00100.x

[26] Huang, W., Li, N., Qiu, Z.J., Jiang, N., Wu, B., Liu, B. (2020). An automatic recognition method for students' classroom behaviors based on image processing. Traitement du Signal, 37(3): 503-509. https://doi.org/10.18280/ts.370318

[27] Lawless, M. S., Baglione, M., Sidebotham, G. W. (2016). Developing and teaching an interdisciplinary musical instrument design course at the cooper union. Journal of the Acoustical Society of America, 139(4): 2096-2096. https://doi.org/10.1121/1.4950223

[28] Zbainos, D., Anastasopoulou, A. (2012). Creativity in Greek music curricula and pedagogy: an investigation of Greek music teachers' perceptions. Creative Education, 3(1): 55-60. https://doi.org/10.4236/ce.2012.31009

[29] Miura, M., Emura, N., Yanagida, M. (2006). An integrated system for learning musical theories from western classical and popular music. Acoustical Society of America Journal, 120(5): 3071-3072. https://doi.org/10.1121/1.4787373

[30] Warrenburg, L. A. (2020). Comparing musical and psychological emotion theories. Psychomusicology, 30(1): 1-19. https://doi.org/10.1037/pmu0000247

[31] Calilhanna, A., Onwubiko, S. G. (2019). Mathematical music theory of embodied acoustics of Ikoro music using beat-class theory. The Journal of the Acoustical Society of America, 146(4): 2999-2999. https://doi.org/10.1121/1.5137386

\section{Authors}

Nan Lin is a graduate student at Tianjin Conservatory of Music, and her research is Music. and she has published 1 paper and participated in 1 professional related topic. 
Jiannan Li is a master's student in art from Hebei University, and her research interests include art theory, music theory, music education, etc., and she has published more than 3 papers and participated in more than 3 professional related topics (email: wzh1986@caztc.edu.cn).

Article submitted 2021-09-25. Resubmitted 2021-10-27. Final acceptance 2021-10-30. Final version published as submitted by the authors. 